\title{
The Effect of Cadmium Absorption on Ghrelin and Malondialdehyde Levels in White Rats (Rattusnorvegicus)
}

\author{
Triawanti, Didik Dwi Sanyoto, Mashuri, and Hendra Wana Nur'amin
}

\begin{abstract}
Cadmium is expected to affect the absorption of other nutrients and appetite through the competition with the nutrients, causing damages to cell membranes through lipid peroxidation reactions. Damaged intestinal cells may disrupt the secretion of one of digestive hormones, ghrelin, theorexigenic hormone. The purpose of this study was to analyze the effect of cadmium exposure on the levels of ghrelin and malondialdehyde (MDA) in rats (Rattusnorvegicus). The study used post-test-only control group design, with 2 groups of white rats: control group (P0) was given placebo and treatment group (P1) was exposed to cadmium. Parameters measured were the levels of MDA and ghrelin. The results showed that there was no difference in body weights $(p=0.057)$ and ghrelin concentrations $(p=0.910)$ between the white rats in the control group and the treatment group. There were significant differences in the levels of MDA. The treatment group had a higher MDA level compared with control $(p=0.001)$. It was concluded that the cadmium exposure for 4 group did not affect the secretion of ghrelin hormone and body weights of white rats, but might cause lipid peroxidation in white rats, as evidenced by the increased MDA level.
\end{abstract}

Index Terms - Cadmium, ghrelin, MDA, body weight.

\section{INTRODUCTION}

South Kalimantan, a province in Indonesia, has many mining areas widely spreaing in several districts. Various mining activities include coal, gold, iron and others exploitation. In addition to the mining activities, there are also several industrial factories, e.g. cement factory. Increased mining and industrial enterprises have some positive impacts in increasing local revenues. However, uncontrolled mining and industries also have adverse effect to the society and the environment. The real impacts are the pollution of water, soil and air by a variety of industrial and mining waste products, including cadmium.

Cadmium is a highly toxic environmental pollutant which has a long half-life in humans. Many studies revealed the nature of the toxic cadmium in humans and experimental animals [1]. Cadmium is a metal stable in the second valence shell, such as CdS. These properties have a detrimental effect

Manuscript received February 25, 2014; revised April 25, 2014.

Triawanti is with the Medical Chemistry Biochemistry Department Faculty of Medicine Lambung Mangkurat University, Banjarmasin, Indonesia (e-mail: tria_fkunlam@yahoo.co.id).

Didik Dwi Sanyoto is with the Medical Anatomy Department Faculty of Medicine LambungMangkurat University, Banjarmasin, Indonesia (e-mail: didikdwisanyoto@gmail.com).

Mashuri is with the Radiology Department Faculty of Medicine Lambung Mangkurat University/Ulin General Hospital, Banjarmasin, Indonesia (e-mail: dr.mashuri@ymail.com).

Hendra Wana Nur'amin is with the Pharmacology Department Faculty of Medicine LambungMangkurat University, Banjarmasin, Indonesia (e-mail: hendranuramin@gmail.com). on the mechanism of absorption of essential mineral elements, e.g. $\mathrm{Fe}, \mathrm{Zn}$, and $\mathrm{Ca}$, which also have second valence shell. The research from Turgut et al. [2] proved that the individuals who were anemic had higher cadmium levels compared with the controls, and hemoglobin, serum iron, mean corpuscular volume, ferrit zin and red blood cells were lower than the controls. It was concluded that there is an influence of cadmium on iron status of the study subjects. Other studies have concluded that anemia in individuals exposed to cadmium was not only due to the competition in gastrointestinal tract, but also because of hemolysis, body iron accumulation and erythropoietin production insufficiency [3].

Cadmium goes through the digestive tract not only because of the competition with other minerals, but it is also thought to be a direct effect on the intestinal mucosal cells, therefore the absorption of the other nutrients can be impaired. Mechanism of cadmium toxicity is not perfectly understood, but increased lipid peroxidation in tissues is observed immediately after exposure to cadmium. Cadmium also causes injuries to the cell membrane. The structures of lipid membranes are varied, which results in changes in cellular membrane fluidity. Cadmium-induced lipid peroxidation disrupts cell membrane integrity and function of the body [1]. If the cells of the intestinal mucosa are disrupted, the absorption and secretion functions of hormones and digestive enzymes are also affected. As a result, individuals who are exposed to cadmium in a long term will have nutrition disorders not only because of anemia, but also because of protein-calorie deficiency due to impaired absorption and lack of appetite.

One of the hormones that play a role in the regulation of appetite is ghrelin. Ghrelin is a unique orexigenic hormone, produced primarily by the stomach and proximal small intestine. In addition to the intestine, ghrelin has also been identified in other peripheral tissues, such as pancreatic, ovarian and adrenal cortex. In the brain, neurons that produce ghrelin have been identified in the pituitary, hypothalamus $\mathrm{ARC}$, and neuron group in the dorsal, ventral, paraventricular and hypothalamic arcuatus nucleus [4]. Ghrelin binds to growth hormone secretory receptor (GHS-R) [4], [5] and has a role in the regulation as opposed to satiation peptides. Ghrelin stimulates the activity of neurons expressing NPY, AgRP and orexin; on the other hand, it suppresses the effect of POMC neurons and CRH-producing neurons [4]. Ghrelin strongly increases food intake, and decreases GI motility and secretion of insulin [6]. If ghrelin production is not adequate or suffered from damages due to the binding to cadmium, a decrease in appetite, and malnutrition may occur.

This study was aimed to determine the effect of cadmium on ghrelin secretion and cell membrane damage, as evidenced by the increased levels of MDA. 


\section{MATERIAL AND METHODS}

\section{A. Material}

The materials used in this study were female white rats (Rattus norvegicus), dissolved Cadmium (Cd), serum, distilled water, TCA $100 \%, \mathrm{HCl} 1 \mathrm{~N}$, and $\mathrm{Na}$ thiobarbituric acid $1 \%$ (made by mixing thiobarbituric acid 0.86 grams, 100 $\mathrm{mL}$ sterile distilled water, and 0.241 grams of $\mathrm{NaOH}$ ), ghrelin hormone, Elisa kit and deionized water.

\section{B. Treatment in Experimental Animals}

The study design used in this study was posttest-only control group design with follow-up. Subjects were 40 female white rats ( $R$. norvegicus) with the age of 10-12 weeks and weighing 180-200 grams. Rats were divided into 2 groups with 16 in each group, namely $\mathrm{P} 0$ : control group, the group of white rats not given $\mathrm{Cd}$ exposure; $\mathrm{P} 1$ : group of white rats given Cd exposure ( $6 \mathrm{mg} / \mathrm{L} /$ day orally for 4 weeks).

Rats were maintained for 1 week before receiving the treatment, to provide similar physical and psychological conditions. During the maintenance, rats were given distilled water and the same food ad libitum. Cadmium solution was made from cadmium powder. A total of $6 \mathrm{mg}$ powder was dissolved in 1 liter of distilled water.

Cadmium was given $2 \mathrm{~mL}$ orally via orogastric tube every day at the same hour. Before it was given, rats were fasted for 3 hours to empty the stomach, so that the solution can be absorbed well. Control group was given placebo solution (distilled water) orally.

\section{Measurement of MDA}

Rat's blood was taken and centrifuged at $3000 \mathrm{rpm}$ for 10 minutes, and the serum was separated. The obtained serum was centrifuged at $6000 \mathrm{rpm}$ for 10 minutes to obtain the supernatant. The supernatant would be used to measure the levels of MDA. A total of $100 \mathrm{uL}$ supernatant, 100uL TCA $100 \%, 250 \mathrm{uLHCl} 1 \mathrm{~N}$ and $450 \mathrm{uL}$ distilled water were mixed. The solution was heated at $100^{\circ} \mathrm{C}$ for 10 minutes, and then it was re-centrifuged at $3000 \mathrm{rpm}$ for 5 minutes. A total of 700 $\mathrm{uL}$ of supernatant was taken and mixed with $2800 \mathrm{uL}$ distilled water. The solution was assessed with a spectrophotometer with the maximum wavelength of 500-600 nm.

Standard solution was diluted to $10,20,30,40,50,60,70$, 80,90 and $100 \mathrm{ng} / \mathrm{mL}$. The absorbance was read immediately with a wavelength of 500-600 $\mathrm{nm}$, to create a standard curve.

\section{Measurement of Ghrelin Levels with ELISA}

Ghrelin Elisa kit, consisting of components of the primary antibody ofanti-ghrelin mouse, biotin-labeled secondary antibodies, reagent, washing reagent and diluting solution, was used. Measurement was conducted in accordance with the procedures of the manufacturer's manual. Elisa Reader read the results with a wavelength of $450 \mathrm{~nm}$.

\section{E. Data Analysis}

The normal distribution of the data obtained was analyzed with Kolmogorov-Smirnov test. Since the distribution was normal, data were analyzed with unpaired t-test. The distribution of ghrelin level data was not normal, and transformation did not change the distribution. Therefore, Mann-Whitney test was used. Confidence level for all the tests was $95 \%$.

\section{RESULTS}

This study used two groups of white rats, namely, the control group and treatment group, each consisting of at least 16 rats. After cadmium exposure $6 \mathrm{mg} / \mathrm{L}$ for 4 weeks was given, the rats were sacrificed and the blood was taken. Levels of MDA and ghrelin hormone were measured. Body weights of each group are presented in Fig. 1.

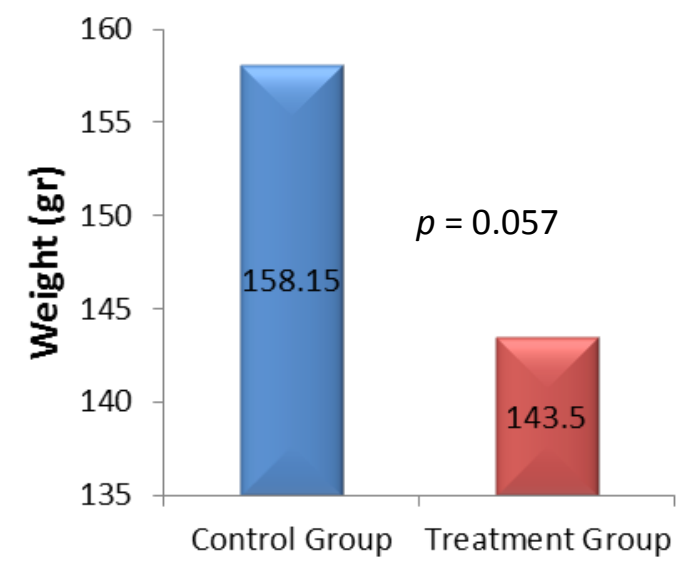

Fig. 1. Average body weights of rats after exposure to cadmium $6 \mathrm{mg} / \mathrm{L}$ for 4 weeks.

Statistical test showed that the body weights of rats in the control group and the treatment were not significantly different $(p=0.057)$. However, there is a tendency that the average body weights of rats in the cadmium group was lower than the control group.

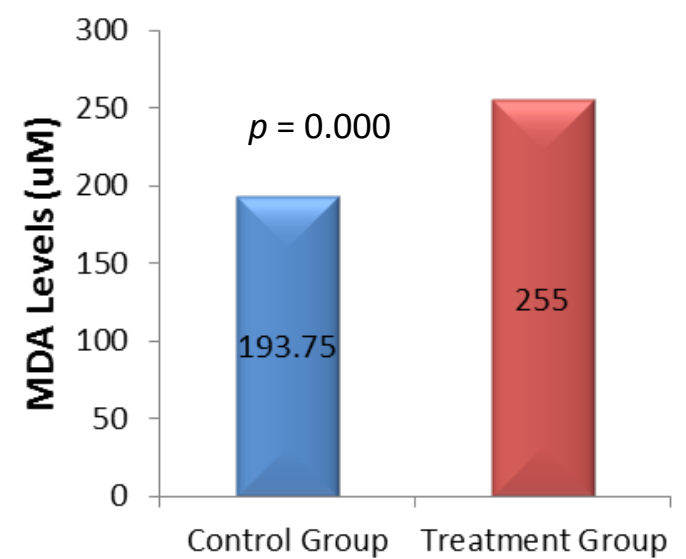

Fig. 2. Average MDA levels of rats after exposure to cadmium $6 \mathrm{mg} / \mathrm{L}$ for 4 weeks.

Statistical test results showed that there was a significant difference $(p<0.05)$ in the levels of MDA between the control group and the treatment group. MDA levels in rats fed with cadmium were higher than the control group. This proves that cadmium has elevated the levels of MDA, which showed that there was the damage to the lipid molecules making up the cell membrane.

Mann-Whitney statistical test results showed that there was no significant difference $(p>0.05)$ in the ghrelin hormone levels of rats between the control group and the treatment group. However, there is a tendency that the average ghrelin in the cadmium group was lower than the control group. 


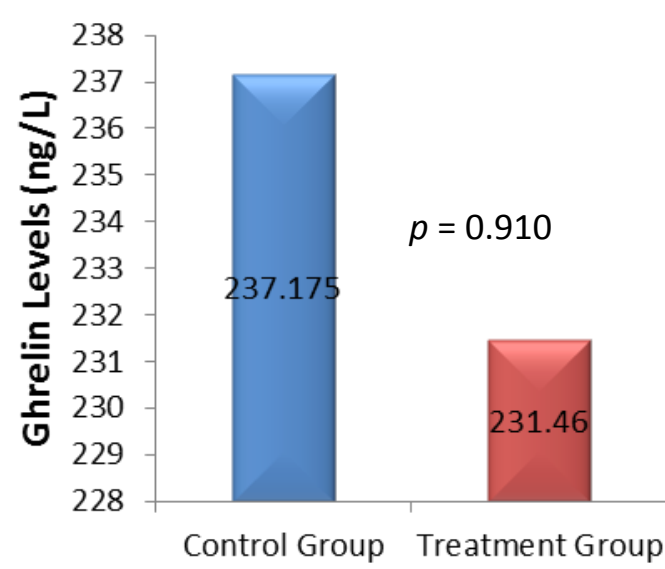

Fig. 3. Average levels of ghrelin after cadmium exposure of $6 \mathrm{mg} / \mathrm{L}$ for 4 weeks.

\section{DISCUSSION}

In general, the absorption and bioavailability of cadmium from food depend on the factor of the food itself, the concentration of cadmium in the food, the nutritional status, sex, smoking status, age, and the presence of divalent and trivalent cations, such as zinc, iron and calcium in the food which compete with cadmium in the absorption process [7], [8]. Cadmium absorption in mice and rats after oral administration of cadmium chloride varies from $0.2-3 \%$ of the administered dose, Which depends on the dose and duration of administration. In human, studies have shown that the absorption of cadmium from food was about $3-5 \%$ [9], [10].

In this study, the cadmium dose administered at $6 \mathrm{mg} / \mathrm{L}$ of drinking water supplied through the orogastric tube as much as $2 \mathrm{~mL}$ (each $2 \mathrm{ml}$ of the drinking water contained $0.012 \mathrm{mg}$ of cadmium). If the cadmium uptake was $0.2-3 \%$ of the administered dose, the amount of cadmium absorbed in rats was only 0.000024 to $0.00036 \mathrm{mg} / \mathrm{day}$. Cadmium is absorbed by the intestinal mucosal cells, and then it enters the blood vessels, and travels to the liver; it is metabolized in the liver and distributed throughout the cells and tissues.

Several studies indicated that cadmium absorption by the intestinal mucosal cells could inhibit the absorption of other minerals, such as iron (Fe) and zinc $(\mathrm{Zn})$, because they had the same valence number. The research from Turgut et al. [2] proved that the individuals who were anemics had higher cadmium levels than the controls; and hemoglobin, serum iron, mean corpuscular volume, ferritin and red blood cells were lower than the controls. It was concluded that there was an influence of cadmium on iron status of the study subjects. Other studies have concluded that anemia in individuals exposed to cadmium was not only due to competition in the gastrointestinal tract, but also because of hemolysis, body iron accumulation and erythropoietin production insufficiency [3].

In this study, we investigated the influence of cadmium on the secretion of ghrelin hormone as an appetite-enhancing hormone. Cadmium absorbed through the digestive tract does not only cause competition among other minerals, but it is also thought to be a direct effect on the intestinal mucosal cells, so that the absorption of other nutrients can be impaired. A mechanism of cadmium toxicity is not perfectly understood, but an increased lipid peroxidation in tissues can be observed immediately after exposure to cadmium. Cadmium also causes injury to the cell membrane. The structures of lipid membranes are varied, which results in the changes in cellular membrane fluidity. Cadmium-induced lipid peroxidation disrupts cell membrane integrity and function of the body [1]. If the cells of the intestinal mucosa are disrupted, the functions of absorption and secretion of hormones and digestive enzymes are also affected. As a result, individuals who are exposed to cadmium in a long term may have nutrition disorders not only because of anemia, but also of protein-calorie deficiency due to impaired absorption and lack of appetite.

The results showed that ghrelin hormone level in the group exposed to cadmium was not different from the control group. This may occur because ghrelin is not only secreted by the cells of the gastric and intestinal mucosa, but also by other peripheral tissues, such as the pancreas, ovaries and adrenal cortex. In the brain, neurons that produce ghrelin have been identified in the pituitary, hypothalamus ARC, and group of neurons in the dorsal, ventral, paraventricular and hypothalamic arcuatus nucleus [4]. Ghrelin binds to growth hormone secretory receptor (GHS-R) [4], [5] and has a role in the regulation as opposed to satiation peptides. Ghrelin stimulates the activity of neurons expressing NPY, AgRP and orexin; on the other hand, it suppressed the effect of POMC neurons and CRH-producing neurons [4]. Ghrelin strongly increases food intake, and decreases GI motility and secretion of insulin [6].

Ghrelin secretion by the stomach depends on nutritional status. Ghrelin level rises in pre-prandial and decreases in post-prandial [4]. Several studies have reported that administration of oligofructose could reduce levels of peripheral ghrelin [10], [11]. Leptin also influences circulating ghrelin levels. It is suspected that the leptin-induced satiety effects include suppression of ghrelin secretion. Working opposite leptin with ghrelin, leptin induces weight loss by suppressing food intake, whereas ghrelin signaling functions as an appetite stimulant. However, several studies reported no link between plasma leptin levels and ghrelin in obese patients. Leptin and ghrelin have different effects on neurons in the hypothalamus that produce a variety of peptides, anorexigenic and orexigenic, which cause opposite effects on energy balance [4].

Ghrelin levels in this study were measured from the circulating blood serum, so the possibility of the secretion of ghrelin from other peripheral tissues could be influenced. Thus, appetite in rats had little influence. This is demonstrated by the non-significantly different body weights of rats given cadmium exposure and the controls. Another thing that is assumed to affect ghrelin levels and body weight of rats is the study period of only 4 weeks. Previous studies generally provided chronic exposure between 8-12 weeks, so that the effects of cadmium toxicity looked more real. In addition, the regulation of appetite is not only played by one kind of hormone. Many mechanisms are involved in the regulation of appetite. To regulate the energy consumption, the brain must modulate appetite. Regulation of appetite is strongly associated with gut axis and brain [6], neurohormonal, and adipose cells [12]-[14]. There are 4 basic parts of the appetite control system: 1) the connection of the autonomic nervous system of the brain, gut and fat cells 2) 
metabolic hormones and molecules produced by adipose cells, 3) the brain neuropeptide (messenger), and 4) messenger molecules of the immune system, especially adipocytokinewith wider effects [15].

In addition, to investigate the effect of cadmium on appetite and body weight of rats, this study also measured the levels of MDA as an indicator of oxidative damage to cell membranes. One of the mechanisms is through the peroxidase reaction of toxic cadmium to cell membrane lipids. Measurement of lipid peroxide is used as an indicator of oxidative stress and tissue cells. Lipid peroxidation is unstable, and it decomposes to produce a number of compounds, including reactive carbonyl compounds. Peroxidation of polyunsaturated fatty acids decomposes to generate MDA and 4 hydroxyl alkene [16]. Peroxidase (auto-oxidation) also occurs in the lipid found in the cell membrane of the intestine. Lipid peroxidation is a free radical chain reaction between the lipids that produce lipid peroxides [17].

In this study, the results showed that MDA levels in white rats exposed to cadmium were significantly higher than the controls. It proves that there has been damages to the tissue cell membranes due to oxidative reactions triggered by cadmium. Other studies have suggested that heavy metal cadmium increased lipid peroxidation in the liver through the formation of Reactive Oxygen Species (ROS). The same damage also appears to be associated with dysfunction of neurons in the hypothalamus, pituitary and testis [18]. It is also explained that cadmium toxicity occurs through its ability to induce the formation of free radicals indirectly, including superoxide radicals, hydroxyl radicals, and nitric oxide. Cadmium-mediated oxidative stress by $\mathrm{H}_{2} \mathrm{O}_{2}$ may trigger an increase in the reduction of the activity of antioxidant enzymes, such as catalase and peroxidase, in conjunction with increased lipid peroxidation and superoxide radical production. In addition, cadmium cannot participate in the redox reaction, but has the ability to produce free radicals [19]-[21].

Several studies have also reported that cadmium affects the formation of $\mathrm{H}_{2} \mathrm{O}_{2}$, which is a major source of free radical formation via the Fenton reaction [20]. The mechanism that explains the indirect role of cadmium in the formation of free radicals is that cadmium can replace iron and copper, and then it increases the amount of free iron and copper, which in turn will play a role in oxidative stress via the Fenton reaction [22], [23].

Despite the evidence of increased levels of MDA in white rats fed with cadmium, this research has not been able to prove that there has also been the damage to the mucosal cells of the stomach and intestines, so it cannot be concluded that the increase in MDA levels was correlated with the decrease in ghrelin and body weight. Correlation between MDA and ghrelin secretion could be demonstrated the MDA and ghrelin levels measured were specifically originate from the gastrointestinal tract, not in systemic blood. In addition, it is necessary to check the microscopic appearance of cells in the gastrointestinal mucosa to prove the damage on the cell membrane.

\section{CONCLUSION}

Based on the results of this study, it can be concluded that there was no significant difference in body weights of white rats and ghrelin levels between controls and white rats exposedwith cadmium. Meanwhile, there was a significant difference in the MDA levelsbetween control group and white rats exposed with cadmium. Giving exposure to cadmium at a dose of $6 \mathrm{mg} / \mathrm{L}$ of drinking water $(0.012 \mathrm{mg}$ cadmium/2 mL) for 4 weeks did not affect the secretion of ghrelin hormone and body weight of white rats, but it might cause lipid peroxidation in white rats, as proved by the increase in MDA levels in white rats exposed with cadmium.

\section{ACKNOWLEDGMENT}

This study is funded by Medical Faculty Lambung Mangkurat University, through Research Grant.

\section{REFERENCES}

[1] S. Demir and G. Öner, "The effects of kadmium on the fragility of red blood cell," Journal of Islamic Academy of Sciences, vol. 8, no. 2, pp. 73-78, 1995.

[2] S. Turgut, S. Hacioglu, G. Emmungil, G. Turgut, and A. Keskin, "Relations between iron deficiency anemia and serum level of copper, Zinc, Cadmium and lead," Polish JEnviron Stud, vol. 18, no. 2, pp. 273-277, 2009.

[3] H. Horuguchi, E. Oguma, and F. Kayama, "Cadmium induces anemia through interdependent progress of hemolysis, body iron accumulation, and insufficient erythropoietin production in rats," Toxicological Sciences, vol. 122, no. 1, pp. 198-210, 2011.

[4] M. D. Klok, S. Jakobsdottir, and M. L. Drent, "Appetite regulatory peptides. The role of leptin and ghrelin in the regulation and body weight in humans: A review," Obesity Reviews, vol. 8, pp. 21-34, 2007

[5] E. V. Dimaraki and A. J. Craig, "Role of endogenous ghrelin in growth hormone secretion, appetite regulation and metabolism," Rev Endocr Metab Disord, vol. 7, pp. 237-249, 2006.

[6] D. E. Cummings and O. Joost, "Gastrointestinal regulation of food intake," Journal of Clinical Investigation, vol. 117, pp. 13-23, 2007.

[7] P. G. Reeves and R. L. Chaney, "Bioavailability as anissue in risk assessment and management of food cadmium: A review," Science of the Total Environment, vol. 398, no. 1-3, pp. 13-19, 2008.

[8] J. Alexander, D. Benford, and A. Cockburn, "Cadmium in food scientific opinion of the panel on contaminants in the food chain," The EFSA Journal, vol. 980, pp. 1-139, 2009.

[9] ATSDR (Agency for Toxic Substances and Disease Registry), "Draft toxicological profile for Cadmium," U.S. Department of health and human Services, Public Health Service, vol.512, 2008.

[10] P. D. Cani, D. Cedric, and M. D. Nathalie, "Inulin-type fructans modulate gastrointestinal peptides involved in appetite regulation (glucagon-like peptide-1 and ghrelin) in rats," British Journal of Nutrition, vol. 92, pp. 521-526, 2004.

[11] N. M. Delzene, D. C. Patrice, D. Catherine, and M. N. Audrey, "Impact of inulin and oligofructose on gastrointestinal peptides," British Journal of Nutrition, vol. 93, suppl. 1, pp. S157-S161, 2005.

[12] J. Auwerx and S. Bart, "Leptin," The Lancet, vol. 351, pp. 737-42, 1998.

[13] A. M. Kempft, L. S. Myra, C. Y. Li, K. Harsohena, and T. K. H. Terry, "Leptin as a marker of body fat and hyperinsulinemia in college students," Journal of American College Health, vol. 55, pp. 175-180, 2006.

[14] A. Corsonello, F. Perticone, A. Malara, D. De Domenico, S. Loddo, M Buemi, R. Ientile, and F. Corica, "Leptin-dependent platelet aggregation in healthy, overweight and obese subjects," International Journal of Obesity, vol. 27, pp. 566-573, 2003.

[15] M. A. Hyman, "Systems biology: The gut-brain-fat cell connection and obesity," Alternative Therapies in Health and Medicine, vol. 12, no. 1, 2006.

[16] B. Halliwel and J. M. C. Gutteridge, Free Radical in Biology and Medicine, 3rd ed., New York: Oxford University Press, 1999.

[17] J. Biem, "Out of the Cold: Management of hypothermia and frostbite," CMAJ, vol. 163, no. 3, 2003.

[18] G. Giusi, R. M. Facciolo, R. Alò et al., "Some environmental contaminants influence motor and feeding behaviors in the ornate wrasse (Thalassoma pavo) via distinct cerebral histamine receptor subtypes," Environmental Health Perspectives, vol. 113, no. 11, 2005.

[19] M. Smiri, A. Chaoui, and E. E. Ferjani, "Interaction between heavy metals and thiol-linked redox reactions in germination," Pakistan Journal of Biological Sciences, vol. 13, no. 18, pp. 877-883, 2010.

[20] A. Galan, L. Garcia-Bermejo, A. Troyano, N. E. Vilaboa, C. Fernandez, E. de Blas, and P. Aller, "The role of intracellular oxidation in death induction (apoptosis and necrosis) in human promonocytic cells treated 
with stress inducers (Cadmium, heat, X-rays)," Eur J Cell Biol, vol. 80, pp. 312-320, 2001

[21] C. Ali, D. M. Réda, R. Rachid, and B. Houria, "Cadmium induced changes in metabolic function of mitochondrial isolated from potato tissue (Solanum tuberosum L.)," American Journal of Biochemistry and Biotechnology, vol. 5, no. 1, pp. 35-39, 2009.

[22] E. Casalino, C. Sblano, and C. Landriscina, "Enzyme activity alteration by Cadmium administration to rats: the possibility of iron involvement in lipid peroxidation," Arch Biochem Biophys, vol. 346, pp. 171-179, 1997.

[23] W. Watjen and D. Beyersmann, "Cadmium-induced apoptosis in C6 glioma cells: influence of oxidative stress," Biometals, vol. 17,pp. 65-78, 2004.

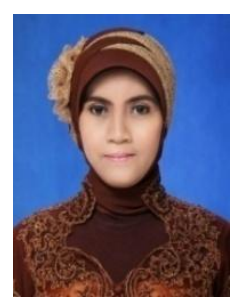

Triawanti was born in Surabaya, Indonesia, in September 1971. She was graduated as a physician in 1998 from Lambung Mangkurat University, Banjarmasin, Indonesia. She was graduated with the master degree in 2002 from Airlangga University, Surabaya, Indonesia, and the $\mathrm{PhD}$ in 2012 from Brawijaya University, Malang, Indonesia.

She currently works in Medical Biochemistry Department, Faculty of Medicine, Lambung Mangkurat University, Banjarmasin, Indonesia.

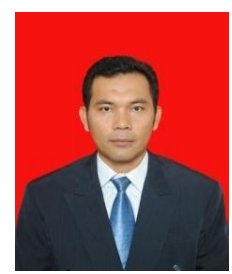

Didik Dwi Sanyoto was born in Pelaihari, Indonesia, in March 1972. He was graduated as a physician in 1998 from Lambung Mangkurat University, Banjarmasin, Indonesia. He was graduated with the master degree in 2003 from Airlangga University, Surabaya, Indonesia. He currently works in Medical Anatomy Department, Faculty of Medicine, Lambung Mangkurat University, Banjarmasin, Indonesia.

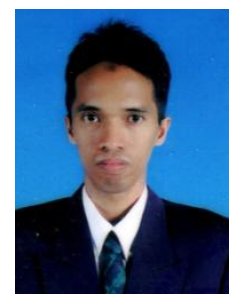

Mashuri was born in Banjar, Indonesia in February 1974. He was graduated as a physician in 2000 from Lambung Mangkurat University. He was graduated with the master degree in 2012 from Padjadjaran University, Bandung Indonesia, Radiologist 2012 from Padjadjaran University, Bandung Indonesia. He currently works in Radiology Department, Faculty of Medicine/Ulin General Hospital, Lambung Mangkurat University, Banjarmasin, Indonesia.

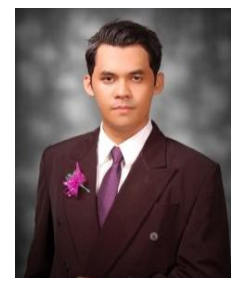

Hendra Wana Nur'amin was born in Kandangan, Indonesia in February 1991. He was graduated as a physician in 2013 from Lambung Mangkurat University. He currently works in Medical Pharmacology Department and Medical Education Unit, Faculty of Medicine, Lambung Mangkurat University, Banjarmasin, Indonesia. 